(c) 2018 - ISSN 1807-2577

\title{
Prevalence and risk indicators of peri-implantitis after 8 to 10 years of function
}

\author{
Prevalência e indicadores de risco de peri-implantite após 8 a 10 anos em \\ função
}

\author{
Cláudio MARCANTONIOa (D), Lélis Gustavo NíCOLIb (D), \\ Carolina Mendonça de Almeida MALZONI ${ }^{b}$ (1), Cristiano SUSINc (1), \\ EIcio MARCANTONIO JUNIOR ${ }^{b^{*}}$ (1), Daniela Leal ZANDIM-BARCELOS ${ }^{\mathbf{b}}$ [1] \\ aUNIARA - Universidade de Araraquara, Programa de Pós-graduação em Implantodontia, Araraquara, SP, Brasil \\ bUNESP - Universidade Estadual Paulista, Faculdade de Odontologia, Departamento de Diagnóstico e Cirurgia, \\ Araraquara, SP, Brasil \\ ${ }^{\circ}$ Chapel Hill University of North Carolina, Department of Periodontology, Capel Hill, USA
}

How to cite: Marcantonio C, Nícoli LG, Malzoni CMA, Susin C, Marcantonio Junior E, Zandim-Barcelos DL. Prevalence and risk indicators of peri-implantitis after 8 to 10 years of function. Rev Odontol UNESP. 2021;50:e20210015. https://doi.org/

\begin{abstract}
Resumo
Introdução: A investigação dos fatores indicadores de risco para as doenças peri-implantares auxilia na prevenção e direcionamento das técnicas de tratamento. Objetivo: 0 objetivo deste estudo transversal foi determinar a ocorrência de peri-implantite e seus potenciais fatores indicadores de risco, além de avaliar as taxas de sucesso e sobrevida em longo prazo dos implantes dentários após 8 a 10 anos de função. Material e método: Foram incluídos cinquenta indivíduos que receberam sua reabilitação implantosuportada entre 2003 e 2005. Dados demográficos, história médica e odontológica foram coletados e um exame clínico completo foi realizado. A análise multivariada foi utilizada para identificar potenciais fatores indicadores de risco relacionados à ocorrência de peri-implantite. Ao todo, 211 implantes foram colocados; 197 estavam em função, 9 ainda estavam submersos e 5 haviam sido perdidos. Resultado: As taxas de sucesso e sobrevivência foram de $81,5 \%$ e 97,6\%, respectivamente. A mucosite peri-implantar afetou 77,1\% dos indivíduos e 52,3\% dos implantes. A peri-implantite foi diagnosticada em 14 indivíduos (29,2\%) e 25 implantes $(12,7 \%)$. Indivíduos com osteoporose $(\mathrm{OR}=2,84)$ e sangramento generalizado à sondagem $(\mathrm{OR}=8,03)$ foram significativamente associados a uma maior chance de peri-implantite. Ao nível do implante, a placa visível $(\mathrm{OR}=4,45)$ e as maiores profundidades de sondagem $(\mathrm{OR}=4,47)$ foram significativamente associadas à peri-implantite. Conclusão: Por meio desses resultados, nosso estudo sugere que a osteoporose e a inflamação generalizada da mucosa periodontal / peri-implantar aumentam a probabilidade de peri-implantite.
\end{abstract}

Descritores: Implantes dentários; taxa de sobrevivência; peri-implantite; fatores de risco.

\begin{abstract}
Introduction: The investigation of peri-implant diseases risk indicators helps to prevent and target treatment techniques. Objective: The aim of this cross-sectional study was to determine the occurrence of peri-implantitis and its potential risk indicator factors, besides to assess the long-term success and survival rates of dental implants after 8 to 10 years of function. Material and method: For this, fifty individuals who had received their implant-supported rehabilitation between 2003 and 2005 were included. Data regarding demographics, medical and dental history were collected and a complete clinical examination was performed. Multivariate analysis was used to identify potential risk indicator factors related to the occurrence of peri-implantitis. Overall, 211 implants had been placed; 197 were in function, 9 were still submerged, and 5 had been lost. Result: Success and survival rates were 81.5\% and $97.6 \%$, respectively. Peri-implant mucositis affected $77.1 \%$ of subjects and $52.3 \%$ of implants. Peri-implantitis was diagnosed in 14 individuals (29.2\%) and 25 implants (12.7\%). Subjects with osteoporosis (OR = 2.84) and generalized bleeding on probing $(\mathrm{OR}=8.03)$ were significantly associated with higher odds of peri-implantitis. At the implant level, visible plaque $(\mathrm{OR}=4.45)$ and deep probing depths $(\mathrm{OR}=4.47)$ were significantly associated with
\end{abstract}


peri-implantitis. Conclusion: Through these results, our study suggests that osteoporosis and generalized periodontal/peri-implant mucosa inflammation increase the likelihood of peri-implantitis.

Descriptors: Dental implants; survival rate; peri-implantitis; risk factors.

\section{INTRODUCTION}

The use of dental implants for oral rehabilitation of patients partially or completely edentulous has become a widely accepted treatment modality. Despite the high success and survival rates of dental implants, early and late failures may occur. Early failures have been associated with inadequate surgical technique, impaired healing, and inadequate occlusal load distribution. Late failures have been linked to peri-implant infection and occlusal overload 1 .

The epidemiology of peri-implantitis is largely unknown, and it has been greatly impacted by the absence of an established diagnostic criteria ${ }^{2}$. Recently, a new classification scheme was performed for periodontal and peri-implant diseases and conditions $^{3}$. This was important to define the diagnostic parameters of these diseases, reducing the results bias of future studies and facilitating disease identification and treatment. Peri-implant diseases are characterized by inflammation of the surrounding peri-implant tissues and subsequent progressive loss of supporting bone. This condition has been associated with patients with a history of periodontal disease and poor plaque control $^{3}$. Peri-implant mucositis is a reversible inflammatory condition, which occurs in the soft tissues around implants. There is strong evidence that plaque induce peri-implant mucositis. This disease is characterized by bleending on probing and visual signs of inflammation $^{3}$. In a recent meta-analysis ${ }^{4}$ forty-seven studies were selected and prevalences of peri-implant diseases were analyzed. Results showed weighted mean implant-based and subject-based peri-implantitis prevalences of $9.25 \%$ and $19.83 \%$ respectively. Regarding periimplant mucositis, weighted mean implant-based and subjectbased were $29.48 \%$ and $46.83 \%$ respectively, clearly underscoring the magnitude of the problem.

Several environmental, behavioral, systemic and oral health factors have been associated with the establishment and progression of peri-implantis, including smoking, history of periodontitis, poor oral hygien, and diabetes ${ }^{4,5}$. Other factors such as genetic factors, osteoporosis, occlusal overload, lack of keratinized mucosa, and implant surface roughness have also been investigated ${ }^{6-9}$. Whereas the amount of evidence linking some of these factors to peri-implantitis has recently increased, proper long-term risk assessment is still scarce in the literature and presents very heterogeneous results.

The aim of this study was to determine the prevalence and risk indicators for peri-implantitis 8 to 10 years after loading. In addition, the long-term success and survival rates of the osseointegrated dental implants were assessed.

\section{MATERIAL AND METHOD}

\section{Study Design and Sample}

A total of 495 partially-edentulous individuals treated with dental implants at the School of Dentistry at Araraquara (UNESP) were invited to participate in this cross-sectional study. They received oral rehabilitation between 2003 and 2005, which allowed the dental implants to be 8 to 10 years in function. Individuals who received at least one implant were eligible to be included in the study. The exclusion 
criteria were individuals that received periodontal treatment and/or antibiotics/anti-inflammatory therapy within the last three months. The protocol of the present study was approved by the Ethics in Human Research Committees of the School of Dentistry at Araraquara (Protocol number CAAE 07513812.3.0000.5416). Written informed consent was obtained from each participant. This study was in accordance with the Helsinki Declaration of 1975, as revised 2004. STROBE guidelines were followed.

Eligible participants were invited to a follow-up visit by telephone calls. Subjects who failed to respond to three consecutive calls in separated occasions were considered uncontactable and were not considered.

\section{Interview and Clinical Examination}

At the 8-10-year follow-up, information such as age, medical history, medications and smoking habits was obtained during an interview with patients using a structured questionnaire. In addition, the number of installed implants and region, characteristics of implants and prosthetic rehabilitation aspects were collected from the patients' records.

The clinical examination was carried out by a single trained and calibrated examiner (L.G.N.). Duplicate exams were done 48 hours apart in $10 \%$ of the sample, and the intra-examiner correlation was 0.80 (Wilcoxon test $\mathrm{p}>0.05$; Spearman correlation $\mathrm{r}=0.81$ ). The following parameters were recorded during the clinical exam: plaque index (PI); gingival index (GI); probing pocket depth (PD); bleeding on probing (BOP); clinical attachment level (CAL), suppuration. PI, GI, BOP and suppuration were registered as presence or absence. These parameters were assessed in four sites per implant or tooth and the other parameters in six sites. A North-Carolina periodontal probe (Hu-friedy®, Chicago, IL, USA) was used for teeth, and a Colorvue ${ }^{\circledR}$ plastic periodontal probe (Hu-friedy®) was used for implants.

A panoramic radiography (Dentsply Sirona ${ }^{\circledR}$, Bonn, Rhineland, Germany) was obtained for each participant for general oral health assessment. Digital periapical radiographs (Saevo®, Ribeirão Preto, São Paulo, Brazil) using a parallel and long cone technique were taken for dental implants. All radiographs were performed at the same oral radiology center.

\section{Case Definitions}

The case definition of periodontitis was determined as the presence of four or more teeth with at least one site with $\mathrm{PD} \geq 4 \mathrm{~mm}, \mathrm{CAL} \geq 3 \mathrm{~mm}$, and BOP. Implant success was defined as absence of signs of inflammation and bleending on probing ${ }^{3}$. Besides that, no peri-implant infection, mobility, persistent pain or dysesthesia, and continuous radiolucency around the implant were accepted ${ }^{10}$. Peri-implant health can exist around implants with normal or reduced bone support ${ }^{3}$. Implant failure was defined as implants that had been lost or removed, or implants that were broken or with mobility. The case definition of peri-implantitis was determined as presence of BOP and/or suppuration, $\mathrm{PD} \geq 5 \mathrm{~mm}$, and radiographic bone loss $\geq 2 \mathrm{~mm}^{11}$. Peri-implant mucositis was defined as presence of BOP and signs of inflammation ${ }^{3}$ with no radiographic active bone loss regardless of the PD value.

The case definitions of diabetes, osteoporosis, thyroid problems, cardiovascular disease and smoking were performed by a questionnaire and the patients should present a medical diagnosis and treatment. For thyroid problems were considered patients with hypo or hyperthyroidism or patients with any dysfunction on thyroid that interfered with hormone production and required drug therapy. For cardiovascular disease were included patients with hypertension, acute myocardial infarction, angina pectoris, heart valve disease, congenital heart disease, endocarditis, cardiac arrhythmias, myocarditis and tumors in the heart. For smoking, patients were divided in patients who never smoked and smoking or ex-smoking patients. 


\section{Data Analysis}

For data analysis, the STATA software (Stata for Mac, version 13, Apple Inc., Cupertino, CA, USA) was used. Preliminary analyzes of the association between peri-implantitis and predictive variables were performed using the chi-square test with Fisher correction for analysis at the level of individuals and the chi-square test adjusted for observations of clusters within individuals for analysis at the level of the implants. Generalized Estimating Equations were used to model the association taking into account the clustering of teeth in individuals. The implant was used as the unit of analysis and exchangeable working correlation, logit link and semi-robust standard errors were used to estimate the "odds ratio" and their respective 95\% confidence intervals. Adjusted and unadjusted analyzes were performed. Statistical significance was set at $5 \%$.

A purposeful selection of variables was used for the statistical modeling ${ }^{12}$. Initially, a preliminary analysis was performed using univariate models, and all the variables associated with $p<0.25$ were included in the multivariate model. The variables that did not contribute significantly to the multivariate model were assessed for confounding before being eliminated. Multivariate models with and without the potential confounding factors were compared and a change $>25 \%$ in the coefficients of the other variables was used to define a variable as a confounding factor. Only age was considered as a confounder and was retained in the final model.

\section{RESULT}

Of all the 495 individuals who received implant surgery between 2003 and 2005, 357 (72\%) patients were not available or could not be located, 61 (12\%) patients declined to participate in the study, and 3 patients passed away. A total of 74 patients agreed to participate, however, only $51(10 \%)$ patients were available for a clinical and radiographic examination, and 1 of these patients was not included in agreement with the exclusion criteria of the study. Thus, the final sample consisted of 50 partially edentulous patients ( 19 males and 31 females) who had received 211 implants with acid etched surface (Porous® Conexão Sistemas de Próteses, Arujá, Brazil). Overall, 206 implants could be evaluated, and they were categorized as follows: 172 successful, 25 failing, 9 submerged, and 5 implants were lost. Thus, the survival rate was $97.6 \%$ and the success rate was $81.5 \%$. Four patients (8\%) had lost implants: one patient lost two implants and the others lost one implant. Of these two patients had lostall their implants. Sample and implant characteristics are described in Table 1.

Table 1. Sample distribution according to subject- and implant-level predictors. Analysis based on 48 subjects and 197 implants, exchangeable correlation, binomial distribution

\begin{tabular}{|c|c|c|c|c|c|}
\hline & & \multicolumn{2}{|c|}{ Subjects } & \multicolumn{2}{|c|}{ Implants } \\
\hline & & $\mathbf{n}^{*}$ & $\%$ & $\mathbf{n}^{*}$ & $\%$ \\
\hline \multicolumn{6}{|c|}{ Subject level variables } \\
\hline \multirow{2}{*}{ Gender } & male & 18 & 37.5 & 79 & 40.1 \\
\hline & female & 30 & 62.5 & 118 & 59.9 \\
\hline \multirow{3}{*}{ Age } & $\leq 40$ & 7 & 14.6 & 24 & 12.2 \\
\hline & $41-64$ & 26 & 54.2 & 94 & 47.7 \\
\hline & $\geq 65$ & 15 & 31.3 & 79 & 40.1 \\
\hline \multirow{2}{*}{ Diabetes } & no & 42 & 87.5 & 170 & 86.3 \\
\hline & yes & 6 & 12.5 & 27 & 13.7 \\
\hline \multirow{2}{*}{ Osteoporosis } & no & 40 & 83.3 & 164 & 83.2 \\
\hline & yes & 8 & 16.7 & 33 & 16.8 \\
\hline \multirow{2}{*}{ Thyroid problems } & no & 40 & 83.3 & 155 & 78.7 \\
\hline & yes & 8 & 16.7 & 42 & 21.3 \\
\hline \multirow{2}{*}{ Cardiovascular disease } & no & 42 & 87.5 & 167 & 84.8 \\
\hline & yes & 6 & 12.5 & 30 & 15.2 \\
\hline
\end{tabular}


Table 1. Continued...

\begin{tabular}{|c|c|c|c|c|c|}
\hline & & \multicolumn{2}{|c|}{ Subjects } & \multicolumn{2}{|c|}{ Implants } \\
\hline & & $\mathbf{n}^{*}$ & $\%$ & $\mathbf{n}^{*}$ & $\%$ \\
\hline \multirow{2}{*}{ Smoking } & never & 33 & 68.8 & 123 & 62.4 \\
\hline & ever & 15 & 31.3 & 74 & 37.6 \\
\hline \multirow{2}{*}{ Full-mouth visible plaque } & $<30$ sites & 37 & 77.1 & 148 & 75.1 \\
\hline & $\geq 30 \%$ sites & 11 & 22.9 & 49 & 24.9 \\
\hline \multirow{2}{*}{ Full-mouth BOP } & $<30$ sites & 20 & 41.7 & 81 & 41.1 \\
\hline & $\geq 30 \%$ sites & 28 & 58.3 & 116 & 58.9 \\
\hline \multirow{2}{*}{ Full-mouth $P D \geq 4 \mathrm{~mm}^{* *}$} & $<10$ sites & 39 & 81.3 & 156 & 79.2 \\
\hline & $\geq 10 \%$ sites & 9 & 18.8 & 41 & 20.8 \\
\hline \multirow{2}{*}{ Full-mouth $\mathrm{CAL} \geq 4 \mathrm{~mm}^{* *}$} & $<30$ sites & 35 & 72.9 & 145 & 73.6 \\
\hline & $\geq 30 \%$ sites & 13 & 27.1 & 52 & 26.4 \\
\hline \multirow{2}{*}{ Periodontitis } & no & 24 & 50.0 & 98 & 49.7 \\
\hline & yes & 24 & 50.0 & 99 & 50.3 \\
\hline \multicolumn{6}{|c|}{ Implant level variables } \\
\hline \multirow{4}{*}{ Location } & Max ant & & & 56 & 28.4 \\
\hline & Max post & & & 41 & 20.8 \\
\hline & Mand Ant & & & 10 & 5.1 \\
\hline & mand Post & & & 90 & 45.7 \\
\hline \multirow{2}{*}{ Visible plaque } & no & & & 114 & 57.9 \\
\hline & yes & & & 83 & 42.1 \\
\hline \multirow{2}{*}{ PD (deepest site) } & $\leq 3 \mathrm{~mm}$ & & & 73 & 37.1 \\
\hline & $\geq 4 \mathrm{~mm}$ & & & 124 & 62.9 \\
\hline \multirow{2}{*}{ Cemented crowns } & no & & & 104 & 52.8 \\
\hline & yes & & & 93 & 47.2 \\
\hline \multirow{2}{*}{ Number of units } & Single & & & 81 & 41.1 \\
\hline & Multiple & & & 116 & 58.9 \\
\hline \multirow{2}{*}{ Crown adaptation } & No & & & 39 & 19.8 \\
\hline & Yes & & & 158 & 80.2 \\
\hline Total & & 48 & 100.0 & 197 & 100.0 \\
\hline
\end{tabular}

BOP, bleeding on probing; PD, probing depth; CAL, clinical attachment level. ${ }^{*} \mathrm{n}=$ number of individuals. ${ }^{* *}$ Parameter evaluated only in teeth.

From 197 implants in 48 subjects clinically evaluated, 103 (52.3\%) implants were diagnosed with mucositis and 25 (12.7\%) with peri-implantitis. At individual level analysis, 37 (77.1\%) patients had mucositis and 14 (29.2\%) had peri-implantitis. The risk indicator factors evaluation for the periimplantitis occurrence was based on the data of 48 patients and 197 implants clinically assessed (Table 2). Peri-implantitis was significantly more prevalent in individuals with BOP (full month) in $30 \%$ or more of the evaluated sites (including teeth and implants). At implant level analysis, peri-implantitis was significantly more frequent in individuals with osteoporosis and BOP in $30 \%$ or more of the evaluated sites.

Table 2. Peri-implantitis distribution according to subject- and implant-level predictors

\begin{tabular}{|c|c|c|c|c|c|c|c|}
\hline & & \multicolumn{3}{|c|}{$\begin{array}{l}\text { Subjects with peri- } \\
\text { implantitis }\end{array}$} & \multicolumn{3}{|c|}{$\begin{array}{l}\text { Implants with peri- } \\
\text { implantitis }\end{array}$} \\
\hline & & No & Yes & $\mathbf{p}^{*}$ & No & Yes & $\mathbf{p}^{*}$ \\
\hline \multicolumn{8}{|c|}{ Subject level variables } \\
\hline \multirow{2}{*}{ Gender } & male & 14 & 4 & & 71 & 8 & \\
\hline & female & 20 & 10 & 0.52 & 101 & 17 & 0.59 \\
\hline
\end{tabular}


Table 2. Continued...

\begin{tabular}{|c|c|c|c|c|c|c|c|}
\hline & & \multicolumn{3}{|c|}{$\begin{array}{l}\text { Subjects with peri- } \\
\text { implantitis }\end{array}$} & \multicolumn{3}{|c|}{$\begin{array}{l}\text { Implants with peri- } \\
\text { implantitis }\end{array}$} \\
\hline & & No & Yes & $\mathbf{p}^{*}$ & No & Yes & $\mathbf{p}^{*}$ \\
\hline \multirow{3}{*}{ Age } & $\leq 40$ & 5 & 2 & & 22 & 2 & \\
\hline & $41-64$ & 20 & 6 & & 85 & 9 & \\
\hline & $\geq 65$ & 9 & 6 & 0.51 & 65 & 14 & 0.38 \\
\hline \multirow{2}{*}{ Diabetes } & no & 30 & 12 & & 148 & 22 & \\
\hline & yes & 4 & 2 & 0.99 & 24 & 3 & 0.80 \\
\hline \multirow{2}{*}{ Osteoporosis } & no & 30 & 10 & & 147 & 17 & \\
\hline & yes & 4 & 4 & 0.21 & 25 & 8 & 0.04 \\
\hline \multirow{2}{*}{ Thyroid problems } & no & 28 & 12 & & 134 & 21 & \\
\hline & yes & 6 & 2 & 0.99 & 38 & 4 & 0.63 \\
\hline \multirow{2}{*}{ Cardiovascular disease } & no & 30 & 12 & & 146 & 21 & \\
\hline & yes & 4 & 2 & 0.99 & 26 & 4 & 0.87 \\
\hline \multirow{2}{*}{ Smoking } & never & 25 & 8 & & 109 & 14 & \\
\hline & ever & 9 & 6 & 0.32 & 63 & 11 & 0.43 \\
\hline \multirow{2}{*}{ Full-mouth visible plaque } & $<30$ sites & 28 & 9 & & 132 & 16 & \\
\hline & $\geq 30 \%$ sites & 6 & 5 & 0.26 & 40 & 9 & 0.22 \\
\hline \multirow{2}{*}{ Full-mouth BOP } & $<30$ sites & 18 & 2 & & 78 & 3 & \\
\hline & $\geq 30 \%$ sites & 16 & 12 & 0.02 & 94 & 22 & 0.01 \\
\hline \multirow{2}{*}{ Full-mouth $P D \geq 4 m^{* *}$} & $<10$ sites & 28 & 11 & & 137 & 19 & \\
\hline & $\geq 10 \%$ sites & 6 & 3 & 0.99 & 35 & 6 & 0.78 \\
\hline \multirow{2}{*}{ Full-mouth $\mathrm{CAL} \geq 4 \mathrm{~mm}^{*}$} & $<30$ sites & 23 & 12 & & 123 & 22 & \\
\hline & $\geq 30 \%$ sites & 11 & 2 & 0.29 & 49 & 3 & 0.22 \\
\hline \multirow{2}{*}{ Periodontitis } & no & 15 & 9 & & 82 & 16 & \\
\hline & yes & 19 & 5 & 0.34 & 90 & 9 & 0.15 \\
\hline \multicolumn{8}{|c|}{ Implant level variables } \\
\hline \multirow{4}{*}{ Location } & Max ant & & & & 51 & 5 & \\
\hline & Max post & & & & 33 & 8 & \\
\hline & Mand Ant & & & & 8 & 2 & \\
\hline & Mand Post & & & & 80 & 10 & 0.58 \\
\hline \multirow{2}{*}{ Visible plaque } & no & & & & 104 & 10 & \\
\hline & yes & & & & 68 & 15 & 0.17 \\
\hline \multirow{2}{*}{ PD (deepest site) } & $\leq 3 \mathrm{~mm}$ & & & & 69 & 4 & \\
\hline & $\geq 4 \mathrm{~mm}$ & & & & 103 & 21 & 0.08 \\
\hline \multirow{2}{*}{ Cemented crowns } & no & & & & 89 & 15 & \\
\hline & yes & & & & 83 & 10 & 0.51 \\
\hline \multirow{2}{*}{ Number of units } & Single & & & & 72 & 9 & \\
\hline & Multiple & & & & 100 & 16 & 0.64 \\
\hline \multirow{2}{*}{ Crown adaptation } & No & & & & 34 & 5 & \\
\hline & Yes & & & & 138 & 20 & 0.79 \\
\hline Total & & 34 & 14 & & 172 & 25 & \\
\hline
\end{tabular}

BOP, bleeding on probing; PD, probing depth; CAL, clinical attachment level. ${ }^{*} \mathrm{p}=\mathrm{p}$ value. Statistical significance $\mathrm{p}<0,05$. **Parameter evaluated only in teeth. 
In the univariate analysis (Table 3$)$, osteoporosis $(\mathrm{OR}=2.48$ ) and generalized BOP $(\mathrm{OR}=6.40)$ were significantly associated with peri-implantitis. A borderline significant association was observed between peri-implantitis and PD $\geq 4 \mathrm{~mm}(\mathrm{p}=0.08)$. No significant associations were observed for other variables. In the multivariate analysis (Table 4), significant associations between peri-implantitis and osteoporosis $(\mathrm{OR}=2.84)$, diabetes $(O R=0.22)$, generalized BOP $(O R=8.03)$, and periodontitis $(O R=0.24)$ were observed at the patient level analysis. At implant level, peri-implantitis was associated with the presence of visible plaque $(\mathrm{OR}=4.45)$ and $\mathrm{PD} \geq 4 \mathrm{~mm}(\mathrm{OR}=4.47)$. Age was retained in the final model because it interacted with other predictors.

Table 3. Univariable analysis of the association between periimplantitis and subject- and implant-level predictors using Generalized estimating equations. Analysis based on 48 subjects and 197 implants, exchangeable correlation, binomial distribution

\begin{tabular}{|c|c|c|c|c|c|}
\hline & & Odds Ratio & \multicolumn{2}{|c|}{$95 \% \mathrm{CI}^{*}$} & $\mathbf{p}^{* *}$ \\
\hline \multicolumn{6}{|c|}{ Subject level variables } \\
\hline \multirow{2}{*}{ Gender } & male & 1 & & & \\
\hline & female & 1.39 & 0.42 & 4.67 & 0.59 \\
\hline \multirow{3}{*}{ Age } & $\leq 40$ & 1 & & & \\
\hline & $41-64$ & 1.15 & 0.24 & 5.37 & 0.86 \\
\hline & $\geq 65$ & 2.26 & 0.51 & 9.99 & 0.28 \\
\hline \multirow{2}{*}{ Diabetes } & no & 1 & & & \\
\hline & yes & 0.84 & 0.21 & 3.38 & 0.80 \\
\hline \multirow{2}{*}{ Osteoporosis } & no & 1 & & & \\
\hline & yes & 2.48 & 1.03 & 5.95 & 0.04 \\
\hline \multirow{2}{*}{ Thyroid problems } & no & 1 & & & \\
\hline & yes & 0.70 & 0.16 & 2.99 & 0.63 \\
\hline \multirow{2}{*}{ Cardiovascular disease } & no & 1 & & & \\
\hline & yes & 1.13 & 0.27 & 4.74 & 0.87 \\
\hline \multirow{3}{*}{ Smoking } & never & 1 & & & \\
\hline & ever & 1.55 & 0.53 & 4.59 & 0.43 \\
\hline & $<30$ sites & 1 & & & \\
\hline Full-mouth visible plaque & $\geq 30 \%$ sites & 1.96 & 0.67 & 5.70 & 0.22 \\
\hline \multirow[t]{2}{*}{ Full-mouth BOP } & $<30$ sites & 1 & & & \\
\hline & $\geq 30 \%$ sites & 6.40 & 1.49 & 27.49 & 0.01 \\
\hline \multirow{2}{*}{ Full-mouth $\mathrm{PD} \geq 4 \mathrm{~mm}^{* * *}$} & $<10$ sites & 1 & & & \\
\hline & $\geq 10 \%$ sites & 1.22 & 0.31 & 4.72 & 0.78 \\
\hline \multirow{2}{*}{ Full-mouth CAL $\geq 4 \mathrm{~mm}^{* * *}$} & $<30$ sites & 1 & & & \\
\hline & $\geq 30 \%$ sites & 0.36 & 0.07 & 1.84 & 0.22 \\
\hline \multirow{2}{*}{ Periodontitis } & no & 1 & & & \\
\hline & yes & 0.45 & 0.16 & 1.32 & 0.15 \\
\hline \multicolumn{6}{|c|}{ Implant level variables } \\
\hline \multirow{4}{*}{ Location } & Max ant & 1 & & & \\
\hline & Max post & 2.41 & 0.59 & 9.83 & 0.22 \\
\hline & Mand Ant & 2.54 & 0.40 & 16.23 & 0.33 \\
\hline & Mand Post & 1.38 & 0.48 & 3.95 & 0.55 \\
\hline \multirow{2}{*}{ Visible plaque } & no & 1 & & & \\
\hline & yes & 2.21 & 0.72 & 6.75 & 0.17 \\
\hline \multirow{2}{*}{ PD (deepest site) } & $\leq 3 \mathrm{~mm}$ & 1 & & & \\
\hline & $\geq 4 \mathrm{~mm}$ & 3.60 & 0.86 & 14.95 & 0.08 \\
\hline
\end{tabular}


Table 3. Continued...

\begin{tabular}{lccccc}
\hline & & Odds Ratio & 95\% CI* & $\mathbf{p}^{* *}$ \\
\hline \multirow{2}{*}{ Cemented crowns } & no & 1 & & & \\
& yes & 0.75 & 0.32 & 1.77 & 0.51 \\
Number of units & Single & 1 & & & \\
& Multiple & 1.26 & 0.48 & 3.32 & 0.64 \\
Crown adaptation & No & 1 & & & \\
& Yes & 0.87 & 0.30 & 2.48 & 0.79 \\
\hline
\end{tabular}

BOP, bleeding on probing; PD, probing depth; $\mathrm{CAL}$, clinical attachment level. ${ }^{*} \mathrm{CI}=$ Confidence Interval. ${ }^{*} \mathrm{p}=\mathrm{p}$ value. Statistical significance $\mathrm{p}<0,05 .{ }^{* * *}$ Parameter evaluated only in teeth.

Table 4. Multivariable analysis of the association between peri-implantitis and subject- and implant-level predictors using Generalized estimating equations. Analysis based on 48 subjects and 197 implants, exchangeable correlation, binomial distribution

\begin{tabular}{|c|c|c|c|c|c|c|c|c|c|}
\hline & & \multicolumn{4}{|c|}{ Full-model } & \multicolumn{4}{|c|}{ Final (reduced) model } \\
\hline & & Odds Ratio & 950 & \% CI* & $\mathbf{p}^{* *}$ & Odds Ratio & 95 & $\% \mathbf{C I}$ & $\mathbf{p}$ \\
\hline \multirow[t]{2}{*}{ Age } & $41-64$ & 0.76 & 0.20 & 2.88 & 0.69 & 1.03 & 0.35 & 3.03 & 0.96 \\
\hline & $\geq 65$ & 2.03 & 0.59 & 7.01 & 0.26 & 2.84 & 0.89 & 9.07 & 0.08 \\
\hline \multirow{2}{*}{ Diabetes } & no & 1 & & & & 1 & & & \\
\hline & yes & 0.17 & 0.03 & 0.86 & 0.03 & 0.22 & 0.05 & 0.87 & 0.03 \\
\hline \multirow{2}{*}{ Osteoporosis } & no & 1 & & & & 1.00 & & & \\
\hline & yes & 2.83 & 1.03 & 7.81 & 0.04 & 2.87 & 1.06 & 7.82 & 0.04 \\
\hline \multirow{2}{*}{ Full-mouth visible plaque } & $<30$ sites & 1 & & & & & & & \\
\hline & $\geq 30 \%$ sites & 1.60 & 0.51 & 5.06 & 0.42 & & & & \\
\hline \multirow{2}{*}{ Full-mouth BOP } & $<30$ sites & 1 & & & & 1.00 & & & \\
\hline & $\geq 30 \%$ sites & 6.56 & 1.69 & 25.54 & 0.01 & 8.03 & 1.95 & 32.98 & 0.004 \\
\hline \multirow{2}{*}{ Full-mouth $C A L \geq 4 m^{* * *}$} & $<30$ sites & 1 & & & & & & & \\
\hline & $\geq 30 \%$ sites & 0.51 & 0.11 & 2.38 & 0.39 & & & & \\
\hline \multirow{2}{*}{ Periodontitis } & no & 1 & & & & 1 & & & \\
\hline & yes & 0.30 & 0.11 & 0.84 & 0.02 & 0.24 & 0.10 & 0.58 & 0.001 \\
\hline \multirow{4}{*}{ Location } & Max ant & 1 & & & & & & & \\
\hline & Max post & 1.92 & 0.39 & 9.50 & 0.43 & & & & \\
\hline & Mand Ant & 3.05 & 0.58 & 15.92 & 0.19 & & & & \\
\hline & Mand Post & 2.14 & 0.65 & 7.02 & 0.21 & & & & \\
\hline \multirow{2}{*}{ Visible plaque } & no & 1 & & & & 1 & & & \\
\hline & yes & 4.42 & 1.39 & 13.99 & 0.01 & 4.45 & 1.43 & 13.89 & 0.01 \\
\hline \multirow{2}{*}{ PD (deepest site) } & $\leq 3 \mathrm{~mm}$ & 1 & & & & 1 & & & \\
\hline & $\geq 4 \mathrm{~mm}$ & 4.70 & 0.91 & 24.43 & 0.07 & 4.47 & 1.09 & 18.35 & 0.04 \\
\hline
\end{tabular}

BOP, bleeding on probing; PD, probing depth; CAL, clinical attachment level. ${ }^{*} \mathrm{CI}=$ Confidence Interval. $* * \mathrm{p}=\mathrm{p}$ value. Statistical significance $\mathrm{p}<0,05 * * *$ Parameter evaluated only in teeth.

\section{DISCUSSION}

In the present study, the reported implant success and survival rates of $81.5 \%$ and $97.6 \%$ respectively, after a period of 8 to 10 years of function, should be considered a very satisfactory 
result. According to Albrektsson et al. ${ }^{13}$, 1986, an implant system could be considered effective if a minimum success rate of $80 \%$ was achieved after 10 years of function. Similar survival rates were obtained in a retrospective study, whose analysis resulted in a 10-year implant survival rate of $98.8 \%$ and a success rate of $97 \%{ }^{11}$.

A high prevalence of mucositis was observed in this study, $77.1 \%$ and $52.3 \%$ at individual and implant level respectively. These results are in accordance with the study of Lindhe, Meyle ${ }^{14}$, that identified the presence of mucositis in $80 \%$ of subjects and $50 \%$ of sites restored with implants. However, a systematic review of $2015^{15}$ evaluated fifteen articles and estimated weighted mean prevalences of peri-implant mucositis of $43 \%$. The concern related with the high prevalence of mucositis is due to the risk of untreated sites developing into periimplantitis ${ }^{16}$, especially if they are not included in a preventive maintenance program. While mucositis can be treated successfully with non-surgical mechanical debridement, this treatment modality has limited efficacy for peri-implantitis. Therefore, the treatment of early sign of inflammation is essential to prevent or limit marginal bone loss ${ }^{17}$.

Peri-implantitis has been considered one of the major reason for late implant loss. However, its prevalence value varies considerable in the literature. According to the systematic review of Derks, Tomasi ${ }^{15}$, the prevalence of peri-implantitis was $22 \%$ (range, 1 to $47 \%$ ). The prevalence of peri-implantitis in our sample amounted $29.2 \%$ at individual level and $12.7 \%$ at implant level. Similar values were reported in other studies. Atieh et al. ${ }^{11}$ reported the occurrence of periimplantitis in $18.8 \%$ of participants and $9.6 \%$ of implants.

For adequate diagnosis and prevention of peri-implantitis, annual radiographic exams are requested from the moment of prosthetic crown placement ${ }^{3}$. However, as this study is a retrospective study and the patients were not in follow-up after implant and prosthetic crown placement, anterior periapical radiographs were not obtained. Therefore, it was not possible to perform a comparative of activity and extension of bone loss caused by the peri-implantitis of each patient. This is a limitation of the study, where we are based on the current clinical and radiographic findings of patients to configure them with periimplant diseases or periimplant health.

Regarding the risk of peri-implant diseases, several authors have reported that subjects with a history of periodontal disease may be at greater risk for implant failure. Schwarz et al. ${ }^{18}$ in a narrative review, showed that there is an increased risk of developing peri-implantitis in patients who have a history of chronic periodontitis, poor plaque control skills and no regular maintenance care after implants therapy. Surprisingly, we identified a negative relationship in the multivariate analysis between the presence of periodontitis and peri-implantitis prevalence $(\mathrm{OR}=0.24)$. This unexpected result may be justified by the parameters used in the present study to define the presence of periodontitis and the comparatively small sample size. On the other hand, our data demonstrate that the presence of sites with $\mathrm{PD} \geq 4 \mathrm{~mm}(\mathrm{OR}=4.47)$ and the presence of visible plaque $(\mathrm{OR}=4.45)$ around the implant were significantly associated with a higher occurrence of peri-implantitis. Moreover, individuals with bleeding on probing in more than or equal $30 \%$ of sites $(\mathrm{OR}=8.03)$ was at a significantly higher risk of developping periimplantitis. The systematic review by Zangrando et al. ${ }^{19}$ showed that patients diagnosed with periodontitis undergoing appropriate therapy and regular maintenance could be successfully treated with dental implants (implant survival rate of $92.1 \%$ after 10 years of follow-up). Residual pockets, noncompliance with a regular maintenance program, and smoking were described as negative factors for long-term implant outcomes.

Although previous studies have found a positive association between smoking habits and periimplantitis prevalence ${ }^{4,20}$ this correlation is contradictory ${ }^{21}$. In the present study, individuals that smoked 10 cigarettes or more per day were considered smokers. Only 2 patients were classified as smokers and 13 patients were former smokers. Thus, smokers and former smokers were included in a single category to enable the statistical analysis. According to our results, the 
smoking habit was not associated with an increased occurrence of peri-implantitis. Ata-Ali et al. ${ }^{21}$ in their prospective cross-sectional study involving heavy smokers and non-smokers may conclude that smoking, when analyzed alone, does not influence immunological and microbiological parameters in dental implants. Although smoking habit is not considered an absolute contraindication for dental implants treatment, it is a relevant factor for the initiation and progression of peri-implantitis and with that, peri-implant mariginal bone $\operatorname{loss}^{17}$.

Guobis et al. ${ }^{22}$ in a systematic review verified that osteoporosis cannot be considered a significant a risk factor for implant success. On the other hand, Alsaadi et al. ${ }^{23}$ reported significant correlation between the osteoporosis and implant failure. The osteoporosis presence was significantly associated with higher peri-implantitis prevalence at individual level in our study $(\mathrm{OR}=2.84)$. Despite our limited sample size, the association between osteoporosis and periimplantitis observed in the present study suggests that this relation needs to be more investigated under other methodological approaches including laboratorial hormonal examinations.

Naujokat et al. ${ }^{24}$ in a systematic review of 22 clinical studies and 20 publications in the aggregate literature concluded that patients with poorly controlled diabetes have impaired osseointegration, a high risk of periimplantitis, and a higher level of implant failure. However, Dowell et al. ${ }^{25}$, evaluating 50 implants in 35 individuals stratified by glycated hemoglobin levels, observed that there was no evidence of clinical failure and healing changes associated with dental implant therapy in individuals with type 2 diabetes mellitus, controlled based on glycated hemoglobin levels. In the present study, the presence of type-2 diabetes mellitus had a protective effect for peri-implantitis $(\mathrm{OR}=0.22)$. However, laboratory tests were not conducted to check the blood sugar levels in the patients considered to have type-2 diabetes. Moreover, there were only six patients with diagnose of diabetes in our sample. Consequently, these limitations could have influenced the results obtained in the present study.

All patients included in this study received implants from the same manufacturer. Therefore, the surface roughness and other implant characteristics could not be evaluated as risk indicators for peri-implantitis. The high patient's evasion observed could be related to the retrospective character of this study where in the recall evaluation was performed after a relatively long period from the prosthetic rehabilitation. These patients were not included in a regular maintenance program after the treatment with osseointegrated dental implants. Most of them (72\%) were not available or could not be located for a clinical and radiographic examination of the implants after 8-10 years of function. Since conflicting results could be observed in the literature regarding risk indicators for peri-implantitis, prospective studies are required in order to determine true risk factors for peri-implantitis.

The success and survival rates of osseointegrated implants after 8-10 years of function were $82 \%$ and $97.6 \%$, respectively. The prevalence of mucositis and peri-implantitis was $52.3 \%$ and $12.7 \%$ for implants and $77.1 \%$ and $29.2 \%$ for patients. Subjects with osteoporosis and with fullmouth BOP scores $\geq 30 \%$ of the sites as well as implants with visible plaque and sites with PD $\geq$ $4 \mathrm{~mm}$ were more susceptible to peri-implantitis. Therefore, our results, notwithstanding the limitations of the study regarding sample size, suggest that osteoporosis, diabetes and generalized periodontal/peri-implant mucosa inflammation increase the likelihood of periimplantiitis.

\section{REFERENCES}

1. Esposito M, Hirsch JM, Lekholm U, Thomsen P. Biological factors contributing to failures of osseointegrated oral implants. (II). Etiopathogenesis. Eur J Oral Sci. 1998 Jun;106(3):721-64. http://dx.doi.org/10.1046/j.0909-8836..t01-6-.x. PMid:9672097.

2. Salvi GE, Lang NP. Diagnostic parameters for monitoring peri-implant conditions. Int J Oral Maxillofac Implants. 2004;19(Suppl):116-27. PMid:15635952. 
3. Caton JG, Armitage G, Berglundh T, Chapple ILC, Jepsen S, Kornman KS, et al. A new classification scheme for periodontal and peri-implant diseases and conditions - Introduction and key changes from the 1999 classification. J Clin Periodontol. 2018 Jun;45(Suppl 20):S1-8. http://dx.doi.org/10.1111/jcpe.12935. PMid:29926489.

4. Lee C-T, Huang Y-W, Zhu L, Weltman R. Prevalences of peri-implantitis and peri-implant mucositis: systematic review and meta-analysis. J Dent. 2017 Jul;62:1-12. http://dx.doi.org/10.1016/j.jdent.2017.04.011. PMid:28478213.

5. Salvi GE, Carollo-Bittel B, Lang NP. Effects of diabetes mellitus on periodontal and peri-implant conditions: update on associations and risks. J Clin Periodontol. 2008 Sep;35(8 Suppl):398-409. http://dx.doi.org/10.1111/j.1600-051X.2008.01282.x. PMid:18724865.

6. Rinke S, Ohl S, Ziebolz D, Lange K, Eickholz P. Prevalence of periimplant disease in partially edentulous patients: a practice-based cross-sectional study. Clin Oral Implants Res. 2011 Aug;22(8):826-33. http://dx.doi.org/10.1111/j.1600-0501.2010.02061.x. PMid:21198898.

7. Dereka X, Mardas N, Chin S, Petrie A, Donos N. A systematic review on the association between genetic predisposition and dental implant biological complications. Clin Oral Implants Res. 2012 Jul;23(7):775-88. http://dx.doi.org/10.1111/j.1600-0501.2011.02329.x. PMid:22151432.

8. Bornstein MM, Cionca N, Mombelli A. Systemic conditions and treatments as risks for implant therapy. Int J Oral Maxillofac Implants. 2009;24(Suppl):12-27. PMid:19885432.

9. Schrott AR, Jimenez M, Hwang J-W, Fiorellini J, Weber H-P. Five-year evaluation of the influence of keratinized mucosa on peri-implant soft-tissue health and stability around implants supporting fullarch mandibular fixed prostheses. Clin Oral Implants Res. 2009 Oct;20(10):1170-7. http://dx.doi.org/10.1111/j.1600-0501.2009.01795.x. PMid:19719741.

10. Buser D, Janner SFM, Wittneben J-G, Brägger U, Ramseier CA, Salvi GE. 10-year survival and success rates of 511 titanium implants with a sandblasted and acid-etched surface: a retrospective study in 303 partially edentulous patients. Clin Implant Dent Relat Res. 2012 Dec;14(6):839-51. http://dx.doi.org/10.1111/j.1708-8208.2012.00456.x. PMid:22897683.

11. Atieh MA, Alsabeeha NHM, Faggion CM Jr, Duncan WJ. The frequency of peri-implant diseases: a systematic review and meta-analysis. J Periodontol. 2013 Nov;84(11):1586-98. http://dx.doi.org/10.1902/jop.2012.120592. PMid:23237585.

12. Hosmer D, Lemeshow S. Applied logistic regression. 3rd ed. New York: Johns Wiley \& Sons; 2000. http://dx.doi.org/10.1002/0471722146.

13. Albrektsson T, Zarb G, Worthington P, Eriksson AR. The long-term efficacy of currently used dental implants: a review and proposed criteria of success. Int J Oral Maxillofac Implants. 1986;1(1):11-25. PMid:3527955.

14. Lindhe J, Meyle J, Group D of European Workshop on Periodontology. Peri-implant diseases: Consensus Report of the Sixth European Workshop on Periodontology. J Clin Periodontol. 2008 Sep;35(8 Suppl):282-5. http://dx.doi.org/10.1111/j.1600-051X.2008.01283.x. PMid:18724855.

15. Derks J, Tomasi C. Peri-implant health and disease. A systematic review of current epidemiology. J Clin Periodontol. 2015 Apr;42(Suppl 16):S158-71. http://dx.doi.org/10.1111/jcpe.12334. PMid:25495683.

16. Lang NP, Berglundh T, Working Group 4 of Seventh European Workshop on Periodontology. Periimplant diseases: where are we now? -- Consensus of the Seventh European Workshop on Periodontology. J Clin Periodontol. 2011 Mar;38(Suppl 11):178-81. http://dx.doi.org/10.1111/j.1600051X.2010.01674.x. PMid:21323713.

17. Klinge B, Meyle J, Working Group 2. Peri-implant tissue destruction. The Third EAO Consensus Conference 2012. Clin Oral Implants Res. 2012 Oct;23(Suppl 6):108-10. http://dx.doi.org/10.1111/j.1600-0501.2012.02555.x. PMid:23062134. 
18. Schwarz F, Derks J, Monje A, Wang H-L. Peri-implantitis. J Periodontol. 2018 Jun;89(Suppl 1):S267-90. http://dx.doi.org/10.1002/JPER.16-0350. PMid:29926957.

19. Zangrando MS, Damante CA, Sant'Ana AC, Rubo de Rezende ML, Greghi SL, Chambrone L. Long-term evaluation of periodontal parameters and implant outcomes in periodontally compromised patients: a systematic review. J Periodontol. 2015 Feb;86(2):201-21. http://dx.doi.org/10.1902/jop.2014.140390. PMid:25272977.

20. Ting M, Craig J, Balkin BE, Suzuki JB. Peri-implantitis: a comprehensive overview of systematic reviews. J Oral Implantol. 2018 Jun;44(3):225-47. http://dx.doi.org/10.1563/aaid-joi-D-16-00122. PMid:29182489.

21. Ata-Ali J, Flichy-Fernández AJ, Alegre-Domingo T, Ata-Ali F, Peñarrocha-Diago M. Impact of heavy smoking on the clinical, microbiological and immunological parameters of patients with dental implants: a prospective cross-sectional study. J Investig Clin Dent. 2016 Nov;7(4):401-9. http://dx.doi.org/10.1111/jicd.12176. PMid:26171870.

22. Guobis Z, Pacauskiene I, Astramskaite I. General diseases influence on peri-implantitis development: a systematic review. J Oral Maxillofac Res. 2016 Sep 9;7(3):e5. http://dx.doi.org/10.5037/jomr.2016.7305. PMid: 27833730.

23. Alsaadi G, Quirynen M, Komárek A, van Steenberghe D. Impact of local and systemic factors on the incidence of late oral implant loss. Clin Oral Implants Res. 2008 Jul;19(7):670-6. http://dx.doi.org/10.1111/j.1600-0501.2008.01534.x. PMid:18492080.

24. Naujokat H, Kunzendorf B, Wiltfang J. Dental implants and diabetes mellitus-a systematic review. Int J Implant Dent 2016. Dec;2(1):5. http://dx.doi.org/10.1186/s40729-016-0038-2. PMid: 27747697.

25. Dowell S, Oates TW, Robinson M. Implant success in people with type 2 diabetes mellitus with varying glycemic control: a pilot study. J Am Dent Assoc. 2007 Mar;138(3):355-61, quiz 397-8. http://dx.doi.org/10.14219/jada.archive.2007.0168. PMid:17332041.

\section{CONFLICTS OF INTERESTS}

The authors declare no conflicts of interest.

\section{${ }^{*}$ CORRESPONDING AUTHOR}

Elcio Marcantonio Junior, UNESP - Universidade Estadual Paulista, Faculdade de Odontologia, Departamento de Diagnóstico e Cirurgia, Rua Humaitá, 1680, 14801-903 Araraquara - SP, Brasil, e-mail: junior.elcio@gmail.com

Received: March 22, 2021

Accepted: April 7, 2021 